\title{
NILAI RAPOR SEKOLAH MENENGAH DAN HUBUNGANNYA DENGAN INDEKS PRESTASI KOMULATIF MAHASISWA
}

\author{
Lukmanulhakim \\ Dosen PAUD FKIP Untan, Pontianak \\ Email;lukmanulhaq@gmail.com
}

\begin{abstract}
Abstrak: Pandangan psikologi kognitif menyatakan bahwa, pengetahuan prasyarat sangat menentukan keberhasilan studi seseorang. Nilai raport sekolah menengah dapat menjadi pengetahuan prasyarat mahasiswa. Asumsi teoritik tersebut di atas perlu dibuktikan kebenarannya. Untuk itu peneliti memiliki masalah yang berkaitan dengan konsistensi hasil belajaran dibuktikan dari nilai raport sekolah menengah dan hubungannya dengan Indeks Prestasi Komulatif. Rumusan masalah penelitian ini adalah: 1) Bagaimana nilai raport sekolah menengah pada mahasiswa Prodi PG PG PAUD FKIP Untan?; 2)Bagaimana Indeks Prestasi Komuatif (IPK) mahasiswa Prodi PG PG PAUD FKIP Untan?; 3)Apakah terhadap hubungan antara nilai raport sekolah menengah dengan Indeks Prestasi Komuatif (IPK) mahasiswa Prodi PG PG PAUD FKIP Untan?. Pendekatan penelitian ini menggunakan metode kuatitatif dengan bentuk studi korelasional.Populasi penelitian ini adalah seluruh mahasiswa Prodi PAUD FKIP Untan dengan sampel 94 orang mahasiswa. Teknik pengumpulan data menggunakan teknik dokumenter dan angket. Data di analisis menggunakan analisis korelasional dengan pendekatan regresi menggunakan program aplikasi SPSS for Windows. Berdasarkan hasil penelitian di atas menunjukkan bahwa rata-rata nilai raport memiliki $\mathrm{N}$ sebanyak 94 dengan nilai rata-rata sebesar 79,675, standar deviasi 6,817, variansi 46,469, nilai minimum 55,60, nilai maksimum 95,81, dan nilai yang paling seringmuncul (modus) 79 . Sedangkan untuk IPK memiliki N sebanyak 94 dengan nilai rata-rata 4,409, standar deviasi 0,234 , variansi 0,055 , nilai minimum 2,71 , nilai maksimum 3,90, nilai yang paling sering muncul (modus) 3,20.Disamping itu, hasil penelitian tersebut menunjukkan nilai Sig adalah 0,231.Karena nilai Sig lebih besar dari $\alpha(0,231>0,05)$, maka dapat disimpulkan bahwa $\mathrm{H}_{0}$ diterima, yang artinya bahwa tidak ada hubungan antara rata-rata raport dengan IPK. Hal ini dapat diartikan bahwa rata-rata nilai raport seseorang tidak mempunyai korelasi dengan IPK yang diperolehnya.Dan hasil penelitian juga menunjukkan nilai bahwa jalur masuk perguruan tinggi seseorang tidak mempunyai korelasi dengan IPK yang diperolehnya. Berdasarkan hasil penelitian yang menyatakan bahwa tidak terdapat hubungan nilai raport dengan Indeks Prestasi Komulatif (IPK), maka penulis mencoba memberikan pembahasan sebagai berikut.
\end{abstract}

Kata Kunci: Nilai Raport Sekolah Menengah, Indeks Prestasi Komulatif (IPK).

\section{PENDAHULUAN}

Hasil pembelajaran berupa Indeks Prestasi Akademik (IPK) mahasiswa sangat dipengaruhi oleh efektifitas perkualiahan. Satu diantara faktor yang mempengaruhi efektifitas pembelajaran tersebut adalah karakteristik si belajar (mahasiswa), demikian Uno dkk (2014).

Reigeluth dan Merill menyatakan hal senada bahwa variabel kondisi pembelajaran meliputi: tujuan, karakteristik bidang studi, kendala dan karakteristik bidang studi dan karakteristik si belajar. Karakteristik si belajar adalah aspek atau kualitas perseorangan mahasiswa seperti: bakat, motivasi dan hasil belajar yang telah dimiliki peserta didik.

Berdasarkan asumsi tersebut, maka dipandang tepat konsistensi nilai rapor semester 3,4 dan 5 pada sekolah menengah digunakan sebagai pertimbangan dalam penerimaan mahasiswa baru jalur Seleksi Nasional Masuk Perguruan Tinggi selama ini. Dari nilai raport tersebut prinsip precditable dalam seleksi dapat terpenuhi, tentu saja dengan harapan nilai raport 
tersebut mempengaruhi keberhasilan studi mahasiswa yang dibuktikan dari indeks prestasi komulatif yang diperolehnya.

Dalam pandangan psikologi kognitif menyatakan bahwa, pengetahuan prasyarat sangat menentukan keberhasilan studi seseorang. Nilai raport sekolah menengah dapat menjadi pengetahuan prasyarat mahasiswa. Asumsi teoritik tersebut di atas perlu dibuktikan kebenarannya. Untuk itu peneliti memiliki masalah yang berkaitan dengan konsistensi hasil belajaran dibuktikan dari nilai raport sekolah menengah dan hubungannya dengan Indeks Prestasi Komulatif.

Mutu SDM terkait mutu proses pembelajaran yang diawali dari mutu inteks masuk perguruan tinggi yang berkualitas.

UU No.12/Tahun 2012 tentang Pendidikan Tinggi mengatur tentang "Penerimaan mahasiswa baru, aantara lain: (1) perguruan tinggi diselenggarakan dengan prinsip pemberdayaan semua komponen masyarakat melalui peran serta dalam penyelenggaraan dan pengendalian mutu layanan pendidikan tinggi; (2) penerimaan mahasiswa baru PTN untuk setiap program studi dapat dilakukan melalui pola penerimaan mahasiswa secara nasional dan bentuk lain; (3) penerimaan mahasiswa baru perguruan tinggi merupakaan seleksi akademik dan dilarang dikaitkan dengan tujuan komerssial; (4) PTN wajib mencari dan menjaring calon mahasiswa yang memiliki potensi akademik tinggi, tetapi kurang mampu secara ekonomi dan calon mahasiswa dari daerah terdepan, terluar, dan tertinggal untuk diterima paling sedikit $20 \%$ dari seluruh mahasiswa baru yang diterima dan tersebar pada semua program studi.

Asas seleksi: (a) predictability, (b) efisiensi, (c) insentive pembelajaran, dan (d) equity atau berkeadilan.

\section{Hasil Belajar}

Standar kompetensi lulusan pendidikan tinggi merupakan kriteria minimal tentang kualifikasi kemampuan lulusan yang mencakup sikap, pengetahuan dan ketrampilan yang dinyatakan dalam rumusan capaian pembelajaran lulusan (CPL) yang digunakan sebagai acuan utama pengembangan standar isi pembelajaran, standar proses pembelajaran, standar penilaian pembelajaran, standar dosen dan tenaga kependidikan, standar sarana dan prasarana pembelajaran, standar pengelolaan pembelajaran dan standar pembiayaan pembelajaran. CPL dirumuskan mengacu pada deskripsi capaian pembelajaran lulusan KKNI dan memiliki kesetaraan dengan jenjang kualifikasi pada KKNI.

Hasil penilaian capaian pembelajaran lulusan pada akhir program studi dinyatakan dengan indeks prestasi komulatif, disingkap IPK yang dinyatakan dalam besaran yang dihitung dengan cara menjumlahkan perkalian antara nilai hurup setiap mata kuliah yang ditempuh dan sks mata kuliah bersangkutan dibagi dengan jumlah sks mata kuliah yang diambil yang telah ditempuh (Permenristekdikti, No. 44/Tahun 2015)

Pada Peraturan Akademik Universitas 2009 menjelaskan Indeks Prestasi Koumulatif (IPK) adalah bilangan dengan dua angka di belakang koma yang menunjukkan kualitas belajar keseluruhan dari materi program studi yang dihitung dengan menjumlahkan hasil perkalian nilai hasil belajar dengan bobot sks dibagi dengan jumlah kredit yang ditetapkan untuk program studi yang bersangkutan

Penjelasan lain, Indeks Prestasi Kumulatif (IPK) adalah tingkat keberhasilan mahasiswa sejak semester pertama sampai semester tertentu/akhir dan dalam perhitungan IPK tersebut setiap mata kuliah hanya diperhitungkan sekali, 
apabila ada pengulangan mata kuliah, maka yang digunakan adalah nilai tertinggi.

Adapun rumus atau formula yang digunakan untuk menentukan IPK adalah sebagai berikut.

Keterangan:

$$
\text { Rumus IPK }=\frac{\sum \mathrm{Kk} \cdot \mathrm{NA}}{\sum \mathrm{Kk}}
$$

NA adalah bobot nilai masing-masing mata kuliah

Kk adalah SKS mata kuliah yang diambil

Mahasiswa dimungkinkan memperbaiki IPK melalui semester biasa dan semester pendek atau semester antara dengan ketentuan diselenggarakan; (1) selama paling sedikit 8 (delapan) minggu; (2) beban belajar mahasiswa paling banyak 9 (sembilan) sks; dan (3) sesuai beban belajar mahasiswa untuk memenuhi capaian pembelajaran yang telah ditetapkan. Apabila semester antara diselenggarakan dalam bentuk perkuliahan, maka tatap muka paling sedikit 16 (enam belas) kali pertemuan termasuk ujian tengah semester dan ujian akhir semester antara (Permenristekdikti, No. 44/tahun 2015).

Pengulangan mata kuliah tersebut dilakukan segera pada tahun akademik berikutnya, baik pada semester pendek maupun semester biasa sampai ujian skripsi dilaksanakan dan mahasiswa yang mengulang mata kuliah harus mengikuti semua kegiatan akademik mata kuliah tersebut pada semester yang bersangkutan. Mahasiswa dapat mengulang mata kuliah dengan persetujuan dosen Pembimbing Akademik (PA).

Besaran Indeks Prestasi Komultif (IPK) berfungsi unutuk; (1) menentukan besarnya jumlah satuan kredit semester (SKS) yang akan diambil pada semester berikutnya dan (2) menilai untuk menilai kemampuan dan keberhasian studi mahasiswa, apakah seorang mahasiswa diperkenankan melanjutkan kegiatan akademik atau tidak (drop-out) dan (3) untuk menentukan kelulusan dengan predikat tertentu, yakni memuaskan, sangat memuaskan dan pujian. Misalnya, kelulusan mahasiswa dari program diploma dan sarjana dengan predikat memuaskan apabila mencapai IPK 2,763,00; predikat sangat memuaskan apabila mencapai IPK 3,01-3,50 dan predikat pujian apabila mencapai IPK lebih dari 3,50. Sedangkan kelulusan mahasiswa program profesi, specialist, magister dan doktor dengan predikat memuaskan apabila mencapai IPK 3,00-3,50; predikat sangat memuaskan apabila mencapai IPK 3,5-3,75 dan predikat pujian apabila mencapai IPK lebih dari 3,75 ke atas.

\section{Hubungan Nilai Raport Sekolah Menengah Atas dengan Indeks Prestasi Komlatif (IPK)}

Hasil pembelajaran berupa Indeks Prestasi Akademik (IPK) mahasiswa sangat dipengaruhi oleh efektifitas perkuliahan. Satu diantara faktor yang mempengaruhi efektifitas pembelajaran tersebut adalah karakteristik si belajar (mahasiswa), demikian Uno dkk (2014).

Reigeluth dan Merill (1979) menyatakan hal senada bahwa variabel kondisi pembelajaran meliputi: tujuan, karakteristik bidang studi, kendala dan karakteristik bidang studi dan karakteristik si belajar. Karakteristik si belajar adalah aspek atau kualitas perseorangan mahasiswa seperti: bakat, motivasi dan hasil belajar yang telah dimiliki peserta didik. Berdasarkan asumsi tersebut, maka dipandang tepat konsistensi nilai rapor semester 3,4 dan 5 pada sekolah menengah digunakan sebagai pertimbangan dalam penerimaan mahasiswa baru jalur Seleksi Nasional Masuk Perguruan Tinggi selama ini. Pendidikan bermutu sangat ditentukan 
oleh pembelajaran efektif, dan pembelajaran efektif dipengaruhi oleh beberapa faktor yang harus diperhatikan dalam penyelenggaraan atau layanan pendidikan.

Faktor-faktor yang dimaksud adalah; (1) ketersediaan dan dukungan pengembangan dan pelatihan profesional pendidik; (2) mekanisme dan proses akuntabilitas, mencakup tata kelola; (3) kurikulum dan kontrol atau penilaian mutu pembelajaran, dan umpan balik pembelajaran; (4) sarana dan prasarana fisik sekolah; (5) kepemimpinan sekolah, organisasi dan budaya sekolah; (6) penjaminan dan sistem dukungan mutu, terutama penjaminan mutu internal; (7) kemitraan orang tua, sekolah dan masyarakat; dan (8) kehadiran dan motivasi peserta didik.

Pendapat lain, terkait prediktor pendidikan bermutu adalah sekolah efektif sebagaimana ditegaskan oleh Peter Martimor (2001) menyebutkan.

\section{"Improving}

School

Effectiveness", yakni sekolah yang memenuhi 11 (sebelas) karakteristik berikut ini; (1) professional leadership; (2) shared vision and goals; (3) learning environment; (4) concentration on teaching and leaning; (5) purposeful teaching; (6) high expectation; (7) positive reinforcement; (8) monitoring progress; (9) pupil right and responsibilities; (10) home-school partnership; dan (11) learning organizatio"

Dari nilai raport tersebut prinsip precditable dalam seleksi dapat terpenuhi, tentu saja dengan harapan nilai raport tersebut mempengaruhi keberhasilan studi mahasiswa yang dibuktikan dari indeks prestasi komulatif yang diperolehnya.

Dalam pandangan psikologi kognitif, pengetahuan prasyarat sangat menentukan keberhasilan studi seseorang. Nilai raport sekolah menengah dapat menjadi pengetahuan prasyarat mahasiswa.

\section{METODE}

Adapun pendekatan penelitian ini adalah penelitian kuantitatif dan bentuk studi korelasional.Adapun populasi penelitian ini adalah mahasiswa aktif Program Studi Pendidikan Guru Pendidikan Anak Usia Dini (PG-PAUD) Fakultas Keguruan dan Ilmu Pendidikan (FKIP) Universitas Tanjungpura. Sampel penelitian ini adalah mahasiswa yang sama namun dilakukan proses pemilihan secara acak dengan pendekatan random sampling.

Dalam menentukan ukuran sampel minimum jika diketahui ukuran populasi (N) diketahui pada taraf signifikansi $(\alpha)=0,5 \%$ menggunakan rumus Taro Yarmanto atau dikenal dengan rumus Slovin sebagai berikut:

$$
n=\frac{N}{N \cdot d^{2}+1}
$$

$n=$ jumlah sampel

$N=$ jumlah populasi

$d=$ besar kelonggaran ketidaktelitian karena kesalahan penarikan sampel

Dengan mensubstitusikan jumlah populasi yang ada, dilakukan perhitungan galat pendugaan atau besar kelonggaran sebesar 5\% akibat ketidaktelitian oleh peneliti sebagai berikut:

Untuk mendapatkan jumlah sampel yang dibutuhkan menggunakan rumus:

$$
\begin{aligned}
& n_{1}=\frac{N_{1}}{N} \cdot n \\
& =\frac{\text { JumlahMahasiswaperkelas }}{\text { JumlahKeseluruhan }} \text {.JumlahKelonggaran }
\end{aligned}
$$

Instrumen penelitian ini adalah data dokumenter tentang nilai indeks prestasi komulatif (IPK) dan nilai Raport Sekolah Menengah Mahasiswa .PG PAUD FKIP 
Universitas Tanjungpura.Adapun teknik pengumpulan data adalah studi dokumenter yang peneliti peroleh di BAAK Universitas Tanjungpura dibatasi tahun akademik 2013/2014 hingga 2015/2016.Adapun analisis data penelitian ini disesuaikan dengan kakateristik data yang bersifat kategori rata-rata raport SMA dan data kontinum untuk indeks prestasi akademik. Oleh karena itu, analisis data penelitan ini adalah analisis korelasional dengan pendekatan regresi dengan menggunakan SPSS for Windows.

\section{HASIL PENELITIAN DAN PEMBAHASAN \\ Hasil Penelitian}

Berdasarkan hasil penelitian di atas menunjukkan bahwa rata-rata nilai raport memiliki N sebanyak 94 dengan nilai ratarata sebesar 79,675, standar deviasi 6,817, variansi 46,469 , nilai minimum 55,60, nilai maksimum 95,81, dan nilai yang paling seringmuncul (modus) 79. Sedangkan untuk IPK memiliki N sebanyak 94 dengan nilai rata-rata 4,409, standar deviasi 0,234 , variansi 0,055 , nilai minimum 2,71 , nilai maksimum 3,90, nilai yang paling sering muncul (modus) 3,20.

Disamping itu, hasil penelitian tersebut menunjukkan nilai Sig adalah 0,231.Karena nilai Sig lebih besar dari $\alpha$ $(0,231>0,05)$, maka dapat disimpulkan bahwa $H_{0}$ diterima, yang artinya bahwa tidak ada hubungan antara rata-rata raport dengan IPK. Hal ini dapat diartikan bahwa rata-rata nilai raport seseorang tidak mempunyai korelasi dengan IPK yang diperolehnya.Dan hasil penelitian juga menunjukkan nilai bahwa jalur masuk perguruan tinggi seseorang tidak mempunyai korelasi dengan IPK yang diperolehnya.

\section{Pembahasan}

Berdasarkan hasil penelitian yang menyatakan bahwa tidak terdapat hubungan nilai raport dengan Indeks Prestasi Komulatif (IPK), maka penulis mencoba memberikan pembahasan sebagai berikut.

Tingkat kepercayaan terhadap nilai raport masih sangat rendah, bahkan ada yang berpendapat bahwa nilai raport yang digunakan dalam seleksi penerimaan mahasiswa baru mengalami inflasi. Semoga asumsi negatif tersebut tidak terbukti kebenarannya.

Semestinya, nilai rapor memenuhi prinsip: kejujuran, independensi, profesionalisme, keadilan, kesejajaran, keterbukaan, akuntabilitas, bertanggung jawab, konfidensial, dan keunggulan.

Seleksi penerimaan mahasiswa baru menggunakan nilai raport. Siswa/i atau calon mahasiswa yang berasal dari sekolah/madrasah dengan nilai raport yang lebih baik memiliki kesempatan lebih besar untuk diterima sebagai calon mahasiswa baru dibanding calon mahsiswa yang berasal dari siswa yang nilai raportnya lebih rendah. Hal ini terjadi karena sistem penilaian yang digunakan dalam seleksi penerimaan mahasiswa baru di perguruan tinggi negeri khususnya mempertimbangkan nilai raport sekolah menengah.

Sistem penerimaan mahasiswa baru yang membedakan calon mahasiswa berdasarkan nilai raport tersebut tidak diikuti sistem atau proses pembelajaran atau perkuliahan yang sesuai dengan potensi yang dimiliki siswa sehingga pembedaan sistem penerimaan yang berdasarkan nilai raport tersebut tidak ada manfaatnya.

Di samping tidak berbeda dalam proses pembelajaran, sistem penilaian dengan nilai raport, penentuan nilai di perguruan tinggi masih sangat 
longgarterlihat dari interval kategori nilai tersebut sehingga instrumen penilaian tersebut tidak memiliki daya pembeda yang menjadi syarat dalam setiap melakukan evaluasi pembelajaran. Padahal secara teoretik penilaian yang baik adalah penilaian yang mampu membedakan potensi akademik peserta didik, dan perlakuannya dalam pembelajaran juga berbeda.

Analisis lain terkait dengan temuan data di atas dipengaruhi pula dengan distribusi kelompok dengan nilai raport tinggi dan nilai rapot rendah. Dalam pembagian kelas tidak dikelompokkkan berdasarkan nilai raport. Berbagai variasi nilai dikelompokkan menjadi satu kelompok prodi. Pola distribusi mahasiswa tersebut berpengaruh terhadap pencapaian IPK mahasiswa. Mahasiswa dengan nilai raport rendah dapat meningkat jika dikelompokkan dengan mahasiswa dengan nilai raport tinggi. Sedangkan mahasiswa dengan mahasiswa dengan nilai raport tinggi akan stagnan pada kualitasnya, artinya kemampuannya tidak meningkat. Dengan demikian kedua criteria mahasiswa jika dilihat dari variasi nilai raport maka nilai IPK-nya akan cenderung merata. Dengan pertimbangan tersebut maka perlu pertimbangan dalam mendistrubusikan mahasiswa berdasarkan kualitasnya. Cara lain menyikapi hal tersebut dengan memberikan variasi beban belajar dan penugasan pada variasi kualitas mahasiswa.

\section{SIMPULAN DAN SARAN}

\section{Simpulan}

1. Rata-rata nilai raport sebesar 79,675 , standar deviasi 6,817, variansi 46,469, nilai minimum 55,60 , nilai maksimum 95,81, dan nilai yang paling sering muncul (modus) 79.

2. Sedangkan untuk IPK memiliki N sebanyak 94 dengan nilai rata-rata
4,409, standar deviasi 0,234 , variansi 0,055 , nilai minimum 2,71, nilai maksimum 3,90, nilai yang paling sering muncul (modus) 3,20.

3. Tidak ada hubungan antara rata-rata nilai raport dengan IPK. Hal ini dapat diartikan bahwa rata-rata nilai raport seseorang tidak mempunyai korelasi dengan IPK yang diperolehnya. Dan tidak ada hubungan antara jalur masuk perguruan tinggi dengan IPK. Hal ini dapat diartikan bahwa jalur masuk perguruan tinggi seseorang tidak mempunyai korelasi dengan IPK yang diperolehnya.

\section{Saran}

1. FKIP Universitas Tanjungpura secara terus menerus berusaha meningkatkan efektivitas proses pembelajaran, meliputi: perencanaan, pelaksanaan dan penilaian.

2. Sekolah harus memberikan nilai raport secara objektif, transparan dan akuntabel dalam mengisi Pangkalan Data Siswa dan Sekolah (PDSS).

3. Kepada peneliti lain disarankan untuk melanjutkan penelitian dengan tema yang sama agar diperoleh pemahanan yang lebih dalam dan komprehenship.

4. Kepada Kemenristekdikti, khususnya kepada panitia seleksi penerimaan mahasiswa baru di PTN dapat mempertimbangkan kembali nilai raport sebagai satu komponen dalam seleksi penerimaan mahasiswa baru.

\section{DAFTAR RUJUKAN}

Laporan Akhir Pelaksanaan SNMPTN 2012,

Panitia Pusat SNMPTN 2012.

Buku Pedoman Akademik Universitas Tanjungpura, Universitas

Tanjungpura, 2014/2015.

Pedoman Akreditasi, Badan Akreditasi Nasional Sekolah/Madrasah, 2014 
Pedoman Penulisan Karya Ilmiah, ReigeluthCM and Merrill, MD (1979) A

Universitas Negeri Malang, 2012

Peraturan Akademik Universitas

Tanjungpura Bidang Pendidikan,

Penelitian dan

Pengabdian kepada Masyarakat,

Pusat Penjaminan Mutu Universitas

Tanjungpura, 2009.

Peraturan Menteri Riset, Teknologi dan

Pendidikan Tinggi RI No.44/Tahun 2015

tentang Standar Nasional Pendidikan

Tinggi, Menristekdikti, 2015
Knowledge Base for Improving Our Methods of Instruction, Education Psychology (13) p. 57-70

Undang-Undang RI Nomor. 12/Tahun 2012 tentang Pendidikan Tinggi.

Uno, Hamzah B; Umar, Marsi Kudrat dan Panjaitan, Keysar (2014), Variabel Penelitian dalam Pendidikan dan Pembelajaran, Jakarta: Ina Publikatama.

Aswandi, 2015. Pendidikan Bermutu untuk Semua. Makalah: Pontianak 